\title{
How Far the Definition of a Refugee under the Refugee Convention 1951 Protects the Victims of Human Rights Abuses? A Review in the Light of Legislation and Case Law of the UK
}

\author{
Md. Salahuddin Mahmud \\ Advocate, Chittagong District Bar Association, Bangladesh and Legal Expert \\ Email: brsmjewel@yahoo.com
}

Doi:10.5901/mjss.2015.v6n2p460

Abstract

The goal of this study is to examine how far the definition of a refugee under the Refugee Convention 1951 protects the victims of human rights abuses. Since time immemorial, torture, inhuman and degrading treatment, religious and political persecution and other violations of human rights have forced people to flee. Thousands of people face persecution worldwide, often due to their religious or political belief, their race or nationality, or other fundamental quality such as their gender and sexuality. To support the victims of this problem the 1951 Refugee Convention was introduced. The purpose of refugee law is to protect people in this position. Nowadays, main causes of refugee movements are armed conflict, large-scale human rights abuses and environmental degradation. I am of the positive and proactive opinion that, as the 1951 Refugee Convention was created for the purpose of giving protection to a specific category of people, thus a large number of victims of the human rights abuses are excluded from the protection. However, it could be possible to protect the victims of human rights abuses sufficiently, if the definition of refugee under the 1951 Refugee Convention is amended through wide interpretation and explanation. In this article doctrinal research method has been applied primarily. This research method has provided various primary and secondary sources to fulfil the purpose of the study.

Keywords: Convention, Human Rights Abuses, Persecution, Protect, Refugee, Well-founded Fear, Victim.

\section{Introduction}

The practice of granting asylum to people feeling persecution in foreign land is one of the earliest hallmarks of civilization. Reference to it have been found in 3,500 years ago, during the blossoming of the great early empires in the Middle East such as Hittites, Babylonians, Assyrians and Ancient Egyptians (UNHCR, Ghana, 1994). The refugee problem is nowadays an important global issue. Throughout the world and over the centuries, societies have welcomed the frightened, weary strangers, the victim of the prosecution and violence. Therefore, to protect the refugees from such situations in 1951 the United Nations introduced a Convention, particularly in relation to refugees, which is known as the UN Convention Relating to the Status of Refugees 1951. This Convention was updated by 1967 Protocol, which removed the time restriction and promoted a gradual removal of the geographical restriction but the refugee definition was not changed. As of 1 October 2002, 141 countries had ratified the Refugee Convention. A detail discussion is necessary to determine the extent whether the definition of a refugee under the 1951 Refugee Convention protects the victims of human rights abuses.

\section{Definition of a Refugee:}

In general, a refugee is a person who takes refuge in another country for fear of persecution or threat to his/ her life. However, the legal definition of a refugee is enshrined in the 1951 Refugee Convention. Article 1(A)( 2) of the 1951 Refugee Convention provides that a 'refugee' is a person who: "owing to a well-founded fear of being persecuted for reasons of race, religion, nationality, membership of a particular social group or political opinion, is outside the country of his nationality and is unable or, owing to such fear, is unwilling to avail himself of the protection of that country; or who, not having a nationality and being outside the country of his former habitual residence . . . is unable or, owing to such fear, is unwilling to return to it" (Clayton, 2012, p.445). In the European Union this definition is now applied by virtue of Refugee Qualification Directive 2004/83/EC (Nadine, 1998, p.321). The Organization of Africa Unity (OAU) Convention Governing the Specific Aspects of Refugee Problem in Africa, a regional treaty adopted in 1967, added to the definition found in the 1951 Convention to include a more objectively based consideration, namely- "Any person compelled to leave 
his/her county owing to external aggression, occupation, foreign domination or events seriously disturbing public order in either part or the whole of his country of origin or nationality"(Convention Governing the Specific Aspects of Refugee Problem in Africa 1969). In 1984, a colloquium of Latin American's government representatives and distinguished jurist adopted the Cartagena Declarations, like the OAU Convention to the 1951 Convention to include: "Persons who flee their countries because their lives, safety or freedom have been threatened by generalized violence, foreign aggression, internal conflicts, massive violation of human rights or other circumstances which have seriously disturbed public order" (Refugee Protection, 2003).

\section{An explanation and discussion on the definition of a refugee under the 1951 Refugee Convention}

From the definition of a refugee as per the 1951 Refugee Convention, a number of characteristics emerge. Firstly, the refugee status claimants' have to be shown that they are outside of their country of origin or nationality $(R v$ Immigration Officer at Prague Airport ex p European Roma Rights Centre [2004] UKHL 50). This means that to be qualified as a refugee, he or she must have crossed an international border (Anker, 2002, 134; Elspeth, 2012, p. 414). However, this provision excludes internally displaced person (Guild, 2009, p.69).

Secondly, they are unable, owing to fear, unwilling to seek or take advantage of the protection of that country (Horvath v SSHD [2000] 3 WLR 379). It means that the claimant has to establish that there is a real risk of serious harm and their state has failed to provide a reasonable level of protection (Bagdanavicius v SSHD [2005] $38 \mathrm{UKHL}$ ).

Thirdly, such inability and unwillingness arises as a consequence of a well-founded fear of being persecuted $(R V$ SSHD ex p Sivakumaran [1988] AC 958).Here two important subject matters are 'well-founded fear' and 'of being persecuted'. The well-founded fear has both subjective and objective tests (UNHCR Handbook, paras 37-50).The subjective aspect of fear refers to the refugee's own experience of fear. The UNHCR hand book discusses the way in which the subjective element may be evaluated, and suggest that the requirement of subjective fear gives scope for taking account of the effect of the circumstances on an individual(UNHCR Handbook, paras 40-41). One of the practical examples of subjective fear is that "one person may have strong political or religious convictions, the disregard of which would make his life intolerable; another may have no such strong convictions" (UNHCR Handbook, paras 40). The proper and usual approach was expressed in the case of Asuming v SSHD (11530) by the tribunal as: "We understand fear in an asylum claim to be nothing more less than a belief in that which the appellant states is likely to happen if he returns to this country of origin ... one should not approach the issue on the basis of a need to access whether a person is 'afraid' in the sense of being fearful rather than courageous"(Asuming $v$ SSHD). The objective aspect of fear refers to the applicant has the burden of proving that their fear is well founded, i.e., there are objective grounds for believing that fear will materialize. Regarding 'well-founded fear' refugee status claimant has to prove that there was real risk or reasonable degree of likelihood that the persecution will be occurred (PS (Srilanka v SSHD) [2008] EWCA Civ 1213; R v SSHD ex $p$ Sivakumaran [1988] AC 958).The 1951 Convention does not define persecution but UNHCR handbook says that the circumstances of each case will determine the nature of the persecution (UNHCR Handbook, paras 52). In the Europe along with the UK, the law in relation to qualification of refugee makes it clear that violation of basic human rights, in particular, which are non-derogable under Article 15 of the European Convention on Human Rights and Fundamental Freedom 1950 (ECHR), will leads to persecution ( Refugee Qualification Directive 2004/83/EC, Articles 9(1) and 9(2); Refugee or Person in Need of International Protection (Qualification) Regulations 2006, SI 2006/2525, Para 5(1); 00 (Sudan) v SSHD [2009] EWCA Civ 1432). It means that the violation of basic human rights has to be sufficiently serious or grave (SH (Palestinian Territories) v SSHD [2008] EWCA Civ 1150). However, the persecution may be occurring due to a single breach of higher category rights (Demirkaya [1999] Imm AR 498). The Refugee Qualification Directive approach to acts of persecution is consistent with the commonly used starting point proffered by Hathaway: "The sustained or systematic violation of basic human rights demonstrative of a failure of state protection in relation to one of the core entitlements which has been recognised by the international community. The types of harm to be protected against include the breach of any rights within the first category (This Category refers to the freedom from arbitrary deprivation of life, from torture, cruel, inhuman or, degrading treatment or punishment, from slavery, imprisonment for breach of contractual obligation, retroactive criminal prosecution, freedom of thought, conscience, and religion, and the right to be recognized as a person in law.) a discriminatory or non-emergency abnegation of a right within the second category (This Category refers to the freedom from arbitrary arrest and detention, right to a fear trial, equal treatment including in access to public employment, freedom of expression, assembly and association, of movement inside a country, to leave and return one's country of origin, to form and join trade unions, to take part in public affairs and vote, and protection for privacy and family.) or failure to implement a right in the third category (This category refers to the right to work, including just and favourable conditions of employment, to an adequate standard of living including food, 
clothing, and housing, to the highest attainable standards of health, to education, and to engage in cultural, scientific , literary, and artistic expression.) which is either discriminatory or not grounded in the absolute lack of resources"(Hathaway, 1991, p.112). The discrimination also may be a reason of persecution which may leads to refugee status (Gashi and Nikshiqi [1997] INLR 96). Discriminatory prosecution or excessive punishment (Shah and Islam v SSHD [1999] 2 A.C. 629) or lack of due process (Khan v SSHD [2003] EWCA Civ 530) may be persecution.

Fourthly, the individual concerned fears of persecution which is based on 'reasons of race, religion, nationality, membership of a particular social group or political opinion' (Sweeney,2009, p.700), and thus a nexus have to be established between fear of persecution and one of the reasons in the Convention (Shah and Islam v SSHD [1999] 2 AC 629). 'Race' is reason under the 1951 Refugee Convention for persecution, but the Convention did not define 'race'. However, it basically refers to 'colour, descent, or membership of a particular ethnic group' (UNHCR Handbook, paragraph 68). In addition, the relevant International Convention also may be sourced in relation to 'race' reason (ICERD, 1966). In the 1951 Convention race is used in the broadest sense and includes an ethnic group of common descent. With regard to race it must be referred to the 1965 Convention on the Elimination of Racial Discrimination which defines that practice to include distinctions based on race, colour, descent, or national or ethnic origin. Persecution on account of race has been the background of many refugee movements. But, lack of specific definition 'race' related persecution was ignored by the court in maximum cases (MA (Palestinian Territories) v SSHD [2008] EWCA Clv 304).

Persecution on the ground of religion is a qualified right (Muslo, K. (2004, p.166). Religion has been one of the reasons for the movement of persons from one country to the other. Article 18 of the 1966 Convention on Civil and Political Rights provides that "every one shall have the right to freedom of thought conscience and religion. This right shall include freedom, either individually or in community with others and in public or private, to manifest his religion or belief in worship, observance, practice and teaching". The concept of the religion includes atheistic beliefs, as well as both participation in and abstention from worship. But, mere declaring the faith illegal by the court will not lead to persecution unless it leads to any suffering of ill-treatment (Ahmad v SSHD [1991] Imm 61).

The word 'nationality' in the Refugee Convention 1951 interpreted broadly and includes the particular ethnic, religious, and linguistic communities. It may include the minority community. The minority community has special physical or religious or cultural traits which are different from those of the dominant segments of the community. However, in practice, the problem with persecution on the basis of nationality is that the scope of nationality has never been fully established (Rehman, 2010, p.650).

The persecution on the ground of 'particular social group' is a broad category and can accommodate a range of entities (Rehman, 2010, p.650). But, where a member of a group share common background and characteristics and that group has a distinct identity to relevant country is considered as a particular social group. It means that the group 'must share something in common other than the persecution' (Savchnkvo [1996] Imm AR 28) but it is not necessary to show cooperation or mutual dependency with each other (Kelly. 2010, p.9). Only group membership for the refugee status claim is not sufficient (Errera, 2007, 164).

The persecution based on 'Political Opinion' refers to the ideas, not tolerated by the authorities, including opinions critical of government policies and method. It includes opinion attributed to the individuals (i.e the authorities think a person has a certain political opinion) even if individual does not in fact hold that opinion. However, to be qualifying the political opinion needs to satisfy that it is relates to the major power transactions taking place in that particular society' (Gomez v SSHD [2001] 1 WLR 549).

\section{The extent of the protection under the 1951 Refugee Convention}

The victims of human rights abuses are concerned with a large number of groups which are divided into many categories. However, the refugees may be treated as one of the categories of the victim of human rights abuses. The humanitarian protections are available to the refugees under the various international conventions and treaties (Universal Declaration of Human Rights 1948 (UDHR), Articles 13, 14 15; European Convention on Human Rights and Fundamental Freedom 1950 (ECHR); UN Convention Against Torture and Other Cruel Inhuman or Degrading Treatment 1987, Article 1(1); International Covenant on Civil and Political Rights 1966 (ICCPR); Geneva Convention relative to the Protection of Civilian Persons in Time of War 1949, Articles 44, 70). However, those international instruments do not directly refer to the refugee protection. Nevertheless, refugees are entitled to get protection because the rights enshrined as global right. On the other hand, the 1951 Refugee Convention imposed obligation on the host state to provide protection to the refugee, such as not to impose penalty or accountability on the unlawfully entered refugee and not to expel or return the refugee in their country of nationality or origin (Refugee Convention 1951, Article 31 (1)). But, this obligation will not be applicable on the host state if the refugee status claimant commits any serious crime as mentioned in the Articles $1 \mathrm{~F}$ and 
33 (2) of the 1951 Refugee Convention (Anti-terrorism, Crime and Security Act 2001, s. 34, Immigration, Asylum and Nationality Act 2006 s.55; Gurung v SSHD [2003] Imm AR 115). According to Article 1F of the 1951 Refugee Convention, if the refugee status seeker has committed serious crime like crime against peace, war crime, crime against humanity ( $R$ (on the application of JS (Srilanka)) v SSHD SK (Zimbabwe) v SSHD [2012] EWCA 807), any non-political crime like terrorism (Terrorism Act 2000; T v SSHD [1996] 2 All ER 865) or any act which is contrary to the principles and purpose of the United Nations (Nationality, Immigration and Asylum Act 2006, s. 54; Al-Sirri v SSHD [2012] UKSC 54), shall be deprived of protection of host state. In practice, it is difficult for a refugee status claimant to establish an issue of crossing borders and flee from the country of origin because the domestic laws are not followed by international standard. In addition, to establish persecution for a Convention reason due to inapplicability of civil war and mass movement situation it is really a problematic issue. Furthermore, many countries in the world facing problem with the refugees are not parties to the 1951 Refugee Convention.

Since from the inauguration of the 1951 Refugee Convention the definition of a refugee under the 1951 convention has been continued to be misunderstood due to the language and media stories. In some context the media stories often confuse refugees with 'economic migrants' and internally displaced persons' (The Rights of Refugees, 2003). Regarding the purpose of 1951 Refugee Convention in Horvath v Home Secretary [2000] 3 W.L.R.379, Lord Hope of Craighead said: "the general purpose of the Convention is to enable a person who no longer has protection against persecution for a Convention reason in his own country to turn for protection to the international community" (p.383). As discussed above in many cases, it appears that the violation of human rights can be a good reason for well-founded fear of persecution, but it was restricted due to the specified condition of the Refugee Convention of 1951 and the nature of the violation of human rights. Though the humanitarian protections for the refugees and the victim of human right abuses' are available under the various international instrument such as UDHR 1948, ECHR 1950, ICCPR 1966, ICERD 1966, UN Convention Against Torture and Other Cruel, Inhuman or Degrading Treatment 1987 and Refugee Qualification Directive 2004/83/EC but due to limitation of definition of refugee under the 1951 Refugee Convention itself is not sufficient to provide protection to the victims of human right abuses'.

\section{Conclusion and Recommendation}

The political, racial, religious, economic and environmental upheavals during the 20th century and at the beginning of the new millennium highlight the relevance of refugee law for human rights. The preamble of the 1951 Refugee Convention also contains the purpose (Feller, 2006, p. 524). As explained above, the definition of refugee under the 1951 Refugee Convention suggests that it is applicable to certain category people and narrowly interpreted. So, ultimately, many victims of human rights abuses are unable to satisfy the requirement of the definition. In addition, all human rights violations are not applicable to the refugees as defined by the 1951 Refugee Convention. However, if the definition of the refugee under the1951 Refugee Convention is interpreted widely likewise Organization of Africa Unity (OAU) Convention Governing the Specific Aspects of Refugee Problem in Africa and Cartagena Declarations of Latin America, then it might be possible to protect the victim of human rights abuses under the Convention not absolutely but at least sufficient.

\section{References}

\section{International Treaties/Conventions}

Universal Declaration of Human Rights 1948 (UDHR)

Geneva Convention relative to the Protection of Civilian Persons in Time of War 1949

European Convention on Human Rights and Fundamental Freedom 1950 (ECHR)

UN Convention Relating to the Status of Refugees 1951

International Covenant on Civil and Political Rights 1966 (ICCPR)

Convention on the Elimination of All Forms of Racial Discrimination 1966 (ICERD)

OAU Convention Governing the Specific Aspects of Refugee Problem in Africa 1969

UN Convention Against Torture and Other Cruel Inhuman or Degrading Treatment 1987

\section{Legislations}

Terrorism Act 2000

Anti-terrorism, Crime and Security Act 2001

Immigration, Asylum and Nationality Act 2006 


\section{Directives}

Refugee Qualification Directive 2004/83/EC

\section{Regulations}

Refugee or Person in Need of International Protection (Qualification) Regulations 2006, SI 2006/2525

\section{Cases}

Ahmad v SSHD [1991] Imm 61

Al-Sirri v SSHD [2012] UKSC 54

Asuming v SSHD (11530)

Bagdanavicius v SSHD [2005] 38 UKHL

Demirkaya [1999] Imm AR 498.

Gashi and Nikshiqi [1997] INLR 96

Gomez v SSHD [2001] 1 WLR 549.

Gurung v SSHD [2003] Imm AR 115

Horvath v SSHD [2000] 3 WLR 379.

MA (Palestinian Territories) v SSHD [2008] EWCA CIv 304

MT (Algeria) and others v SSHD [2007] EWCA Civ 808

Khan v SSHD [2003] EWCA Civ 530.

PS (Srilanka v SSHD) [2008] EWCA Civ 1213;

$R$ v Immigration Officer at Prague Airport ex p European Roma Rights Centre [2004] UKHL 50

$R v$ SSHD ex p Sivakumaran [1988] AC 958.

Savchnkvo [1996] Imm AR 28.

$R$ (on the application of JS (Srilanka)) v SSHD SK (Zimbabwe) v SSHD [2012] EWCA 807.

SH (Palestinian Territories) v SSHD [2008] EWCA Civ 1150.

Shah and Islam v SSHD [1999] 2 A.C. 629.

$T \vee S S H D[1996] 2$ All ER 865

\section{Books}

Clayton G. (2012) Textbook on Immigration and Asylum Law. (5th ed.). Oxford: Oxford University Press. Guild, E. (2009).Security and Migration in the 21st Century. (2nd ed.). Cambridge: Polity Press.

James C. Hathaway. (1991) The Law of Refugee Status. (2nd ed.). Cambridge: Cambridge University Press.

Rehman, J.(2010) International Human Rights Law , (2nd ed.). England: Pearson Longman.

\section{Journals}

Brendan Kelly. (2010).'What is a "particular social group"? A review of the development of the Refugee Convention in England '. Journal of Immigration Asylum and Nationality Law, 24, 9.

D. E. Anker. (2002). 'Refugee Law, Gender, and the Human Rights Paradigm' Harvard Human Rights Journal, 15, 134.

Elspeth Guild. (2012) 'The European geography of refugee protection - exclusions, limitations and exceptions from the 1967 Protocol to the present' European Human Rights Law Review European Human Rights Law Review,17, 414.

Errera, R.(2007). 'Refugee status - membership of a particular social group (Art.1 s.A(2) of the 1951 Geneva Convention relating to the Status of Refugees - sexual orientation' Public Law, 6, 164.

Nadine El-Enany(1998). 'Who is the new European refugee?' European Law Review, 33, 313;

Sweeney, J.(2009) 'Credibility, Proof and Refugee Law'. International Journal of Refugee Law, 21, 700.

\section{Websites}

Convention Goverming the Specific Aspects of Refugee Problem in Africa 1967 [Online]. Aviliable: http://www.au.int/en/sites/default/files/Convention_En_Refugee_Problems_in_Africa_AddisAbaba_10September1969_0.pdf (November15, 2014).

Refugee Protection, International Organization for Migration. [online] Aviliable: http://www.rcmvs.org/documentos/IOM_EMM/v3/V3S05_CM.pdf (November 15, 2014).

International Convention on the Elimination of All Forms of Racial Discrimination 1966.[Online] Available: http://www.ohchr.org/EN/Professionallnterest/Pages/CERD.aspx (17 November, 2014).

International Covenant on Civil and Political Rights. [Online] Aviliable: http://www.ohchr.org/en/professionalinterest/pages/ccpr.aspx (17 November, 2014). 